This is a preprint of the version accepted for ISGT Asia 2017.

The full copy is at https://doi.org/10.1109/ISGT-Asia.2017.8378439

\title{
Saving on household electric water heating: What works best and by how much?
}

\author{
P.J.C. Nel*, M.J. Booysen*, B. van der Merwe ${ }^{\dagger}$ \\ ${ }^{*}$ Department of Electrical and Electronic Engineering, Stellenbosch University, Stellenbosch, South Africa. \\ ${ }^{\dagger}$ Department of Computer Science, Stellenbosch University, Stellenbosch, South Africa. \\ Email:mjbooysen@sun.ac.za
}

\begin{abstract}
Electric heating of water for domestic use is a substantial component of total household energy costs. Thermal energy in a water heater is either used (as warm water) or lost to the environment. Various approaches to reduce the losses and improve the efficiency of these notoriously inefficient and costly water heaters have been proposed and are employed. However, given the complex factors at play, making sense of the savings approaches and choosing the right one for the right use case is not a simple task and often misunderstood. This paper addresses this problem by comparing some of the commonly employed approaches, including schedule control, change in set temperature, use of thermal insulation, and reduction in consumed volume. We also compare the impact of environmental factors, such as changing the ambient temperature around the water heater and the cold inlet temperature. The results show that for the consumption profiles and use cases evaluated, schedule control is the most effective, followed by insulation of the tank and piping. Combined, these two interventions save up to $25 \%$. We also find that the effect of the temperature of the cold inlet water dwarfs that of the ambient temperature, is in line with other approaches, and means the installation status quo needs to be reconsidered.
\end{abstract}

Index Terms-Understanding; perception; electric water heaters

\section{INTRODUCTION}

Household water heating, which accounts for as much as $32 \%$ of household electricity consumption where Electric Water Heaters (EWHs) are used, is notoriously ineffecient and costly in terms of energy consumed.

EWHs consume energy through two main factors: Standing losses and consumption. Standing losses (thermal energy losses to the environment) is as a result of the temperature difference between the water in the EWH tank and the temperature of it's surroundings, and is a function of thermal insulation of the EWH and surrounding pipes to the environment The energy lost due to use is equal to the nett effect of the warm water leaving the EWH and the cold water entering the EWH. The thermal energy in the water (enthalpy) is a function of the volume of warm water used and temperature of the water used.

Therefore, the energy consumed to heat water can be managed through several approaches that address these factors. The approaches include curtailment actions, such as shortening shower times (i.e. reducing the volume of water consumed) or lowering the set temperature of the appliance. Furthermore,

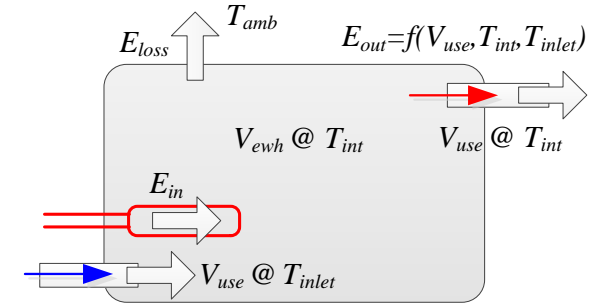

Fig. 1. One-node state energy flow.

users can implement efficiency actions that include the installation of a thermal blanket or pipe insulation. A user can also use timer control to intermittently switch the EWH on and off, which has been shown to reduce the standing losses by as much as $16 \%$ [1].

Other factors that influence the energy consumption of the EWH that the user has less control over after installation are: tank size, as a larger tank surface area causes larger environmental losses if the water in the tank is underutilised; the ambient temperature around the EWH, which impacts the standing losses since the temperature difference is greater; and cold water inlet temperature, which impacts the usage losses in two ways: the water consumed is replaced by colder water that needs to be reheated, but also that more or hotter warm water is required to create the desired temperature at warm water outlets if the mixed cold water's temperature is lower.

The one-node lumped model of an EWH is shown in Figure 1

\section{A. Standing losses and ambient temperature}

The ambient temperature has a direct influence on the standing losses of an EWH. This is because the amount of heat dissipated by the EWH tank is proportional to the temperature difference between the air outside the EWH tank and the water inside the EWH tank. The norm is to have water in the EWH heated to maintain specific set temperature, which makes warm water available from the EWH at any time during the day, regardless of the users' consumption patterns. This results in excessive thermal losses into the environment, especially for users with lower usage (e.g. single shower once a day).

Standing losses refer to the energy lost due to heat dissipation from the water inside the EWH to the outside environment 
as a result of the temperature difference. Standing losses can be modelled as a first order differential equation that describes the temperature decay toward the ambient temperature:

$$
\frac{d T_{i n t}}{d t}=\frac{-A G}{c V_{\text {ewh }}}\left(T_{i n t}-T_{a m b}\right)
$$

Where: $\mathrm{T}_{\text {int }}$ is the temperature of the water in the $\mathrm{EWH}$ in degrees Kelvin; $A$ is the surface area of the EWH that is exposed to the environment; $G$ is the thermal conductivity of the EWH tank in $W /\left(K m^{2}\right)$; and $\mathrm{T}_{a m b}$ is the temperature of the outside environment.

\section{B. Inlet and ambient temperature (Seasonal variation)}

Water that is withdrawn from the EWH is replaced with cold water from the inlet pipe. The temperature of this water determines the amount of energy lost by the tank as a result of a usage event. The balance of energy lost through a usage (or withdrawal) event (e.g. a bath or shower) is the difference of energy in the warm outlet water and in the the cold inlet. Put differently, the energy lost is the energy required to reheat the cold water to the same temperature as the volume of warm water that was used. The energy loss through usage over a sample interval is given by

$$
E_{\text {use }}=c V_{\text {use }}\left(T_{\text {int }}-T_{\text {inlet }}\right)
$$

where $E_{u s e}$ is the energy in $W h, V_{u s e}$ is the volume used in litres, and the difference in temperatures in degrees Kelvin or Celsius. Inlet temperature values vary seasonally with soil temperature, however, the inlet temperature can be affected with a "preheating" phase, for example extended piping inside the house, or a preheating tank.

\section{Contribution}

This paper evaluates the impact of various energy savings actions for electric water heaters including: thermal blankets; pipe insulation; reduction in usage volumes; impact of ambient and inlet temperatures (seasonal and installation variations); reduction in set temperature; EWH tank size; use of schedule/optimised control. The paper uses various representative use cases for one- and three-person households - One person has higher portion of energy used by standing losses and three person has higher portion of energy consumption coming energy consumed by hot water usage events increases. Lookup tables are provided to cover various permutations.

The rest of this paper is organised as follows: section II describes related work in examining the impact of various energy savings actions on EWH energy consumption; section III describes the methodology used to determine the baseline energy consumption values and the development of the simulator used; section IV discusses the results of the simulations; and section $\mathrm{V}$ concludes the paper.

\section{RELATED WORK}

Fikru and Gautier [2] investigated the impact of weather variation on energy consumption for two residential houses with similar size and location in Tyler, Texas. One of the homes was a conventional house with advanced efficiency
TABLE I

AVERAGE DAILY ENERGY CONSUMPTION FOR VARIOUS SEASONS [2]

\begin{tabular}{c|c|c|c}
\hline \multirow{2}{*}{ Season } & \multicolumn{2}{|c|}{ Energy Usage $(\mathbf{W h})$} & \multirow{2}{*}{ Temperature } \\
\cline { 2 - 3 } & House 1 & House 2 & \\
\hline Summer & 937.7 & 746.15 & $27.2^{\circ} \mathrm{C}\left(81^{\circ} \mathrm{F}\right)$ \\
\hline Fall & 911.7 & 588.8 & $16.1^{\circ} \mathrm{C}\left(61^{\circ} \mathrm{F}\right)$ \\
\hline Winter & 1558.3 & 1347.7 & $10^{\circ} \mathrm{C}\left(50^{\circ} \mathrm{F}\right)$ \\
\hline Spring & 761.97 & 720.7 & $21.1^{\circ} \mathrm{C}\left(70^{\circ} \mathrm{F}\right)$ \\
\hline
\end{tabular}

features (e.g. insulation in wall framing and high-efficiency compact fluorescent lighting) and the other was a net-zero solar house with additional efficiency features (e.g. highefficiency and longer life light emitting diode lighting). They defined the units of heating and cooling degree minutes (HDM and CDM, respectively) which refer to the difference in temperature between an minute's average temperature and a given threshold temperature, which is considered to be a standard temperature that doesn't require heating or cooling (i.e. $70^{\circ} \mathrm{F}$ for heating and $76^{\circ} \mathrm{F}$ for cooling). Weather data and household energy consumption were logged at 5 minute intervals for approximately 16 months. During this time the houses were unoccupied and therefore no appliances were running, except the air conditioner, which was set to maintain a temperature of approximately $21^{\circ} \mathrm{C}$ (i.e. $70^{\circ} \mathrm{F}$ ). Their results indicate that, on average, a $1^{\circ} \mathrm{F}$ increase in HDM results in an increased energy usage of approximately $9 \%$ and $5 \%$ for house 1 and 2, respectively. Similarly, a $1^{\circ} \mathrm{F}$ increase in CDM caused an increase of approximately $5 \%$ and $4 \%$ in the energy consumption of house 1 and 2, respectively. Additionally, it was found that the sensitivity of energy to use to weather depends on the season as well as the specific time of day or night. Furthermore, from the results of Table I, it is clear that the energy consumption of households varies significantly with the seasons.

Dutkiewicz [3] investigated the potential savings that can be achieved by various energy saving actions for EWHs based on the warm water requirements of typical middle income families in South Africa. This includes the impact of adding pipe and tank insulation in order to increase the thermal resistance of the system. The replacement of an EWH with an instant heater is also considered but is not considered optimum. This is because of the increased requirements of cabling and the installation cost of a 3-phase supply required to accommodate the increased wattage $(21 \mathrm{~kW})$ of the instant heater. Finally, Dutkiewicz highlights the importance of educating consumers on how to save energy for their EWHs (e.g. not running warm water unnecessarily or overfilling baths).

Bosman et al [4] investigated the impact of installing thermal blankets on the standing losses of standard EWHs in South Africa. The increased thermal resistance of the EWH reduces the standing losses of the device as heat is dissipated to the environment at a slower rate. The study included eighteen identical EWHs in a residential complex in Potchefstroom. Six of the EWHs were fitted with thermal blanked and periods where no warm water consumption occurred were used to determine the standing losses of the EWH. This data is then used to determine a linear approximation of the standing 
losses as a function of ambient and set temperature. It was determined that the standing losses of these devices could be decreased by $18 \%$ on average. It was also found that reducing the set temperature of an $\mathrm{EWH}$ from $75^{\circ} \mathrm{C}$ to $55^{\circ} \mathrm{C}$ would result in twice the reduction on standing losses than installing a thermal blanket.

Gelažanskas and Gamage [5] analysed a set of hot water consumption data from residential households in order to forecast the hot water demand. The dataset consists of a 95 months worth of warm water consumption data obtained from 95 households, sampled in 1 hour intervals. Analysis of this data showed strong daily and weekly usage patterns for individual households but a wide variety of patterns between dwellings. Their results indicate that prediction methods can be used for DSM applications that are aimed at controlling EWH loads without compromising users' comfort.

Booysen et al [1] examined the effect of implementing timer control which only heats water prior to usage for a typical 150 litre EWH. The usage profile is assumed to consist of one 75 litre warm water usage event every 12 hours. This would be the equivalent of almost 3 consecutive typical showers in South Africa [6]. The results of this analysis indicate that, even for the high usage profile assumed, the total energy consumption of the EWH can be reduced by approximately $15 \%$ if an efficient schedule is implemented. It should be noted that, although water heating should only occur before major usage events, enough water could be heated during these times to allow the EWH to still supply warm water for smaller usage events (e.g. washing dishes) that may occur in the interval between the major usage events.

\section{EXPERIMENTAL SETUP}

This section describes: the development of the baseline values of energy consumption for various usage profiles; and the parameters modelled by the simulations used in this paper.

\section{A. Baseline Energy Consumption}

In order to determine the baseline amount of energy consumed by EWHs, several usage profiles, shown in Table II, were created which include major warm water usage events (i.e. baths and showers). For profiles with 1 usage event, the event is assumed to occur at 06:00. For profiles with 2 usage events, the events are assumed to occur within 12 hours of one another. For example, profile 6 has one shower and one bath occurring once at 06:00 and 18:00, respectively. For profiles with 3 usage events, the 2 usage events are assumed to within 12 hours of one another, while the third usage event is assumed to occur with the first usage event at 06:00. For example, profile 6 has one bath and one shower occurring once at 06:00 and one shower occurring at 18:00.Profile 8 consists of 4 usage events and assumes one shower and one bath occur together at both 06:00 and 18:00.

A typical shower in South Africa consumes 59.1 litres of water in total [6], while a bath consumes . Furthermore, the desired temperature (i.e. mixed temperature) of the water at the shower outlet is typically $40.2^{\circ} \mathrm{C}$ [6]. This implies that the volume of warm water at $65^{\circ} \mathrm{C}$ required to create a typical shower event is 26.53 litres. Based on the assumption that the amount of energy used by an event will remain constant for different warm water temperatures [7] and that water at the inlet temperature is at baseline energy [1]:

$$
E_{\text {usage }}=m_{\text {usage }} c \Delta T[k W h]
$$

Where: $E_{\text {usage }}$ is the total energy used by the event; $m_{\text {usage }}$ is the mass of warm water consumed by the event; and $\Delta T$ is the difference in temperature between the inlet and set temperatures. Solving Equation 3:

$$
E_{\text {usage }}=(26.53)\left(1.1611 \times 10^{-3}\right)(65-20)=1.39 \mathrm{kWh}
$$

Therefore, a typical shower event can be assumed to consume approximately $1.39 \mathrm{kWh}$ of energy. The amount of energy consumed by both usage events and standing losses for each of the profiles used for this analysis is summarised in Table II. The standing losses are calculated by assuming that the warm water in the EWH tank is at the nominal warm water temperature setting for EWHs in South Africa (i.e. $65^{\circ} \mathrm{C}$ ) [8]. The amount of energy dissipated by standing losses was calculated using the simulator described in the following section.

\section{B. Simulator Setup}

A two-node physical model of an EWH, presented in [9], is used to simulate the thermodynamic response (and therefore energy consumption) of an individual EWH. This model was validated using consumption data from a household EWH which included $\mathrm{x}$ days and $\mathrm{y}$ usage events. The model is able to estimate the energy consumption of an EWH with an accuracy of 5 and 2 percent for thermostat and schedule control respectively.

The following values were used to establish the baseline energy consumption of an EWH for this analysis: 150 litre tank size; set temperature of $65^{\circ} \mathrm{C}$; no pipe insulation or thermal blanket installed; regular thermostat control (i.e. heating allowed all day); and an inlet and ambient temperature of $20^{\circ} \mathrm{C}$.

For the pipe insulation and thermal blanket variables, the thermal resistance of the system was increased by 6\% [3] and $18 \%$ [4] respectively. For schedule control, the EWH started heating water 2 hours before the occurrence of a usage event and stopped heating 15 minutes before the usage event occurrence.

\section{RESUlts}

The reduction in the total EWH energy consumption as a result of various energy saving initiatives is summarised in Figure 2. The results show that, in general, schedule control achieves by far the biggest saving, resulting in savings ranging from $9 \%$ to $16 \%$. The biggest savings, as expected are the schedules where only one event occurs per day. The second most effective savings are achieved through insulation of the pipes and the tank, with savings ranging from $5 \%$ to $12 \%$. From these results, it can be seen that initiatives that lower the standing losses of the EWH (e.g. schedule control) have the highest impact on profiles that have lower water usage (e.g. profiles 1 and 5). This is because the standing losses constitute a larger portion of the total energy consumed by the EWH 
TABLE II

BASELINE ENERGY CONSUMPTION FOR TYPICAL USAGE PROFILES.

\begin{tabular}{|c|c|c|c|c|c|}
\hline & \multicolumn{2}{|c|}{ Usage events } & \multicolumn{3}{c|}{ Energy consumption } \\
\hline Profile \# & \# Showers & \# Baths & $\begin{array}{c}\text { Standing } \\
\text { losses (kWh) }\end{array}$ & $\begin{array}{c}\text { Usage } \\
\text { energy (kWh) }\end{array}$ & $\begin{array}{c}\text { Total } \\
\text { energy (kWh) }\end{array}$ \\
\hline 1 & 0 & 1 & 2.577 & 1.876 & 4.453 \\
\hline 2 & 0 & 2 & 2.572 & 3.752 & 6.324 \\
\hline 3 & 1 & 1 & 2.575 & 3.262 & 5.837 \\
\hline 4 & 1 & 2 & 2.555 & 5.138 & 7.693 \\
\hline 5 & 1 & 0 & 2.581 & 1.386 & 3.967 \\
\hline 6 & 2 & 0 & 2.579 & 2.772 & 5.351 \\
\hline 7 & 2 & 1 & 2.558 & 4.648 & 7.206 \\
\hline 8 & 2 & 2 & 2.538 & 6.524 & 9.062 \\
\hline
\end{tabular}

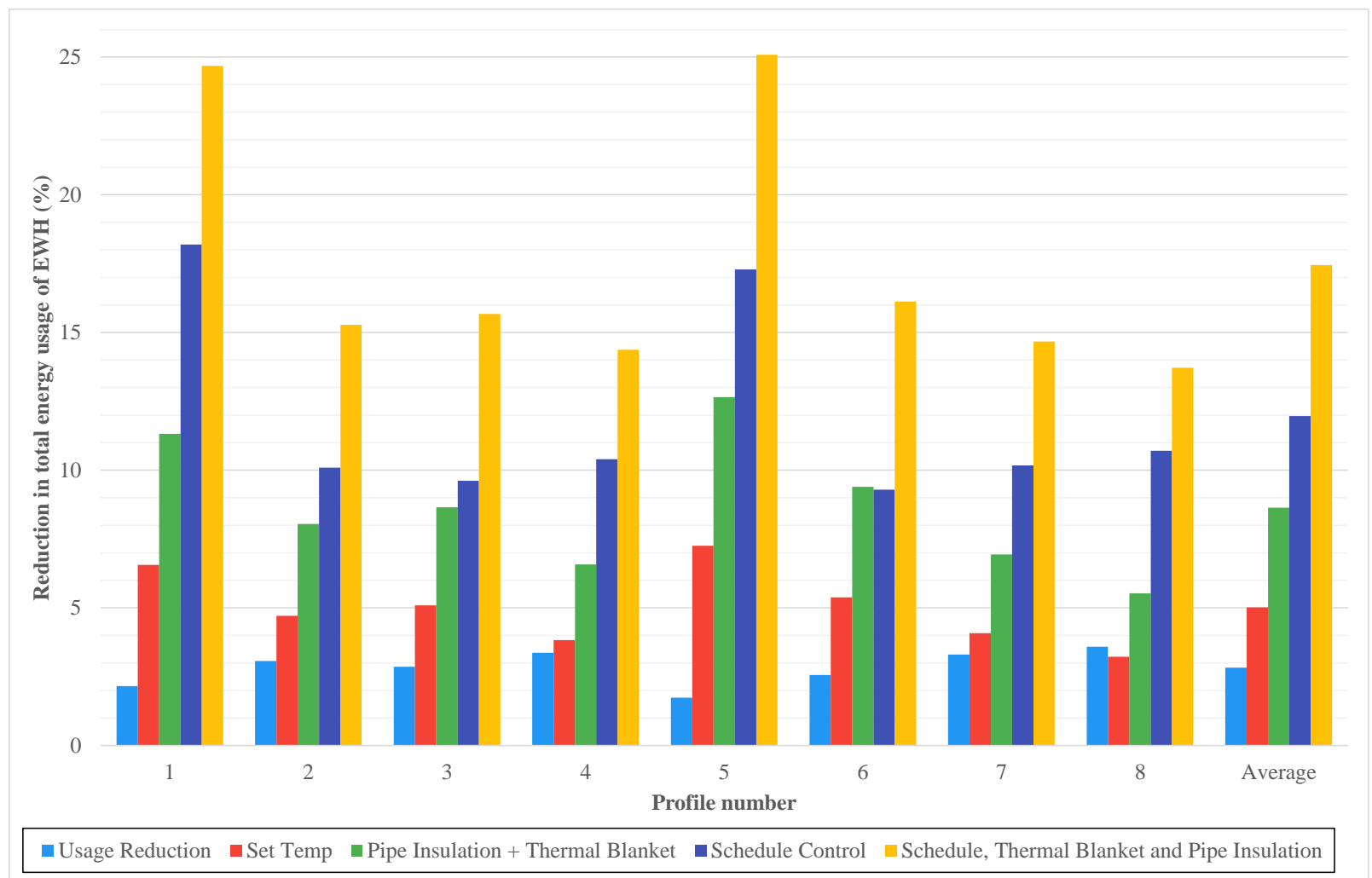

Fig. 2. Bar graph showing the reduction in the total energy consumption of an EWH for each profile shown in Table II as a result of: a 5\% reduction in the volume of usage events ("Usage Reduction"); a $5^{\circ} \mathrm{C}$ reduction in the set temperature of the EWH ("Set Temperature"); the installation of pipe insulation and a thermal blanket ("Pipe Insulation + Thermal Blanket"); implementing schedule control to only heat water before it is required ("Schedule control"); as well as a combination of implementing schedule control and installing pipe insulation and a thermal blanket ("Schedule, Thermal Blanket and Pipe Insulation"). From these results, an average reduction of $17.45 \%$ can be achieved if schedule control is implemented in combination with the installation of a thermal blanket and pipe insulation.

for these low-use profiles. However, even for higher volume water usage profiles, such as profile 8 (which has 4 major usage events), the reduction in the total energy consumption as a result of reduced standing losses is still significant. For example, the total reduction in energy consumption as a result of implementing schedule control for profile 8 is $10.7 \%$.

The effect of ambient temperature is important as device placement can have a significant impact on this variable. For example, if this device is placed outside on a roof, it would experience significantly lower ambient temperatures that if it were positioned in an attic area.

The impact of seasonal variations is illustrated in Figure 3 for the different consumption profiles It is clear from these results that, despite the importance of ambient temperature, the effect of the inlet water's temperature is much more significant, except for profile 5, where a single shower occurs every day (i.e. very little cold water is let in). This shows that a mechanism where the inlet pipes are allowed to reach room temperature, or naturally pre-heated, before entering the EWH, will lead to significantly more savings than any change to the ambient temperature around the tank will have. Savings achieved through increasing the inlet temperature by a mere $5 \%$ leads to a reduction in energy consumed of more than $16 \%$ for the profiles where many big events occur (e.g. profiles 4 and 8).

The results of the simulations for various energy saving actions and seasonal variations in variables are summarised in Tables III and IV for single- and three-person households 


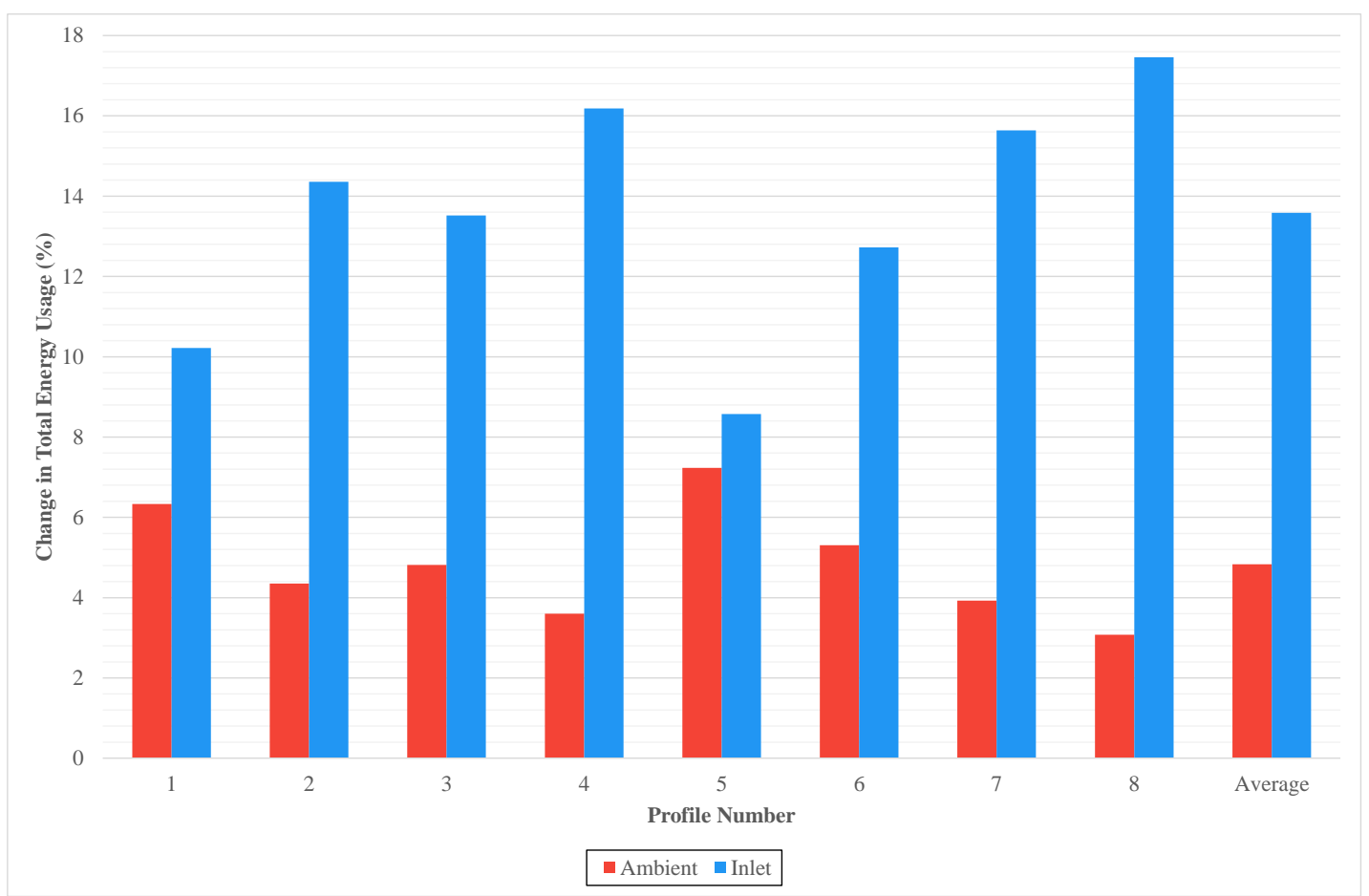

Fig. 3. Bar graph showing the increase in the total energy consumption of an $\mathrm{EWH}$ for each profile shown in Table II as a result of: a $5^{\circ} \mathrm{C}$ decrease in the temperature of the water entering through the inlet pipe ("Inlet"); and a $5^{\circ} \mathrm{C}$ decrease in the ambient temperature of the air surrounding the EWH ("Ambient"). From these results, it is clear that the inlet temperature has a significant impact on the energy consumption of the EWH, especially for profiles with higher usage volumes (e.g. profiles 4 and 8 ).

respectively.

\section{A. Device Efficiency/Settings}

From the results in Table III, the set temperature value of the EWH has a significant impact on the energy consumption for a single-person household. By simply decreasing the set temperature of the $\mathrm{EWH}$ by $5^{\circ} \mathrm{C}$ (to $60^{\circ} \mathrm{C}$ ), a single-person household can achieve a similar total EWH energy reduction as reducing their warm water consumption by $20 \%$. Furthermore, this same reduction can be achieved by installing a thermal blanket and pipe insulation. This is because the standing losses constitute a larger portion of the EWH energy consumption for lower occupancy households. Therefore, reducing the standing losses has a larger impact on the total EWH energy consumption for these households

The results in Table IV indicate that reducing the set temperature of the $\mathrm{EWH}$ by $5^{\circ} \mathrm{C}$ would result in the same reduction in EWH energy consumption as reducing the volume of water consumed by usage events by approximately $12 \%$ for a 3-person household. Additionally, this same reduction can also be realised by installing both a thermal blanket and pipe insulation on an EWH implementing thermostat control for a set temperature of $65^{\circ} \mathrm{C}$. Furthermore, the results indicate that the inlet temperature has almost twice the effect on the energy consumption of the EWH for a three-person household than for a single-person household. This is as a results of the higher usage volumes from higher occupancy households, with a $5^{\circ} \mathrm{C}$ change in inlet temperature causing a change in approximately $15.7 \%$ of the total EWH energy consumption for 3-person households (compared to $8.6 \%$ for single-person households).

Schedule control is efficient because it shouldn't require any sort of behavioural change if implemented correctly. In other words, an effective schedule will be able to deliver hot water on demand while minimising the standing losses of the EWH.

For both single- and three-person households, the results indicate that schedule control has the most significant impact on the standing losses of the EWH. When schedule control, pipe insulation and a thermal blanket are implemented in combination the EWH energy consumption can be significantly reduced, resulting in total EWH average energy reductions of $25.1 \%$ and $14.7 \%$ for single- and three-person households respectively.

\section{CONCLUSION}

This paper evaluated the age-old question of how to best save energy used for household water heating. Various methods were evaluated, including changing the set temperature, reducing volume consumed, insulating the tank and the piping around it, and applying schedule control. These were comparing using eight representative usage profiles. The results show that schedule control has the most significant impact on savings, saving as much as $18 \%$ for infrequent use profiles, and an average of $12 \%$ for all profiles. Thermal insulation saves as much as $12 \%$ for low-volume infrequent use, and an average of almost $9 \%$ across profiles. The results also shows that the temperature of the cold inlet water has a significant impact on energy consumption, with a $5 \%$ increase leading to 
TABLE III

ENERGY IMPACT ANALYSIS RESULTS FOR ONE-PERSON HOUSEHOLD.
TABLE IV

ENERGY IMPACT ANALYSIS RESULTS FOR THREE-PERSON HOUSEHOLD.

\begin{tabular}{|c|c|c|c|c|c|c|}
\hline Variable & Value & $\begin{array}{c}\text { Standing } \\
\text { losses } \\
(\mathbf{k W h} / \mathbf{d a y})\end{array}$ & $\begin{array}{c}\text { Usage } \\
\text { energy } \\
(\mathbf{k W h} / \mathbf{d a y})\end{array}$ & $\begin{array}{c}\text { Total EWH } \\
\text { energy } \\
(\mathbf{k W h} / \mathbf{d a y})\end{array}$ & $\begin{array}{c}\text { Total EWH } \\
\text { energy } \\
(\mathbf{k W h} / \mathbf{m o n t h})\end{array}$ & $\begin{array}{c}\text { Total } \mathbf{~ H H} \\
\text { energy } \\
(\mathbf{k W h} / \mathbf{m o n t h})\end{array}$ \\
\hline Baseline & $\mathrm{N} / \mathrm{A}$ & 2.581 & 1.386 & 3.967 & 120.663 & 212.0 \\
\hline$T_{\text {set }}$ & $55^{\circ} \mathrm{C}$ & 2.003 & 1.386 & 3.389 & 103.082 & 194.419 \\
\hline & $60^{\circ} \mathrm{C}$ & 2.294 & 1.386 & 3.680 & 111.933 & 203.270 \\
\hline$T_{\text {ambient }}$ & $70^{\circ} \mathrm{C}$ & 2.868 & 1.386 & 4.254 & 129.392 & 220.61 \\
\hline & $10^{\circ} \mathrm{C}$ & 3.155 & 1.386 & 4.541 & 135.385 & 229.459 \\
\hline$T_{\text {inlet }}$ & $15^{\circ} \mathrm{C}$ & 2.868 & 1.386 & 4.254 & 129.392 & 220.730 \\
\hline & $10^{\circ} \mathrm{C}$ & 2.575 & 2.072 & 4.647 & 141.346 & 232.683 \\
\hline$V_{\text {usage }}$ & $15^{\circ} \mathrm{C}$ & 2.578 & 1.729 & 4.307 & 131.005 & 222.342 \\
\hline & $-5 \%$ & 2.582 & 1.317 & 3.899 & 118.595 & 209.932 \\
\hline & $-10 \%$ & 2.582 & 1.248 & 3.830 & 116.496 & 207.833 \\
\hline Thermal blanket & $-15 \%$ & 2.582 & 1.178 & 3.760 & 114.367 & 205.704 \\
\hline Pipe insulation & N/A & 2.583 & 1.109 & 3.692 & 112.298 & 203.635 \\
\hline $\begin{array}{c}\text { Thermal blanket } \\
+ \text { pipe insulation }\end{array}$ & N/A & 2.457 & 1.386 & 3.573 & 108.679 & 200.016 \\
\hline Schedule control & N/A & 1.096 & 1.386 & 3.843 & 116.89 & 208.228 \\
\hline $\begin{array}{c}\text { Schedule control } \\
+ \text { thermal blanket } \\
+ \text { pipe insulation }\end{array}$ & N/A & 1.586 & 1.386 & 3.482 & 105.911 & 197.248 \\
\hline 200 litre tank & N/A & 3.016 & 1.386 & 4.402 & 133.894 & 225.231 \\
\hline
\end{tabular}

\begin{tabular}{|c|c|c|c|c|c|c|}
\hline Variable & Value & $\begin{array}{c}\text { Standing } \\
\text { losses } \\
(\mathbf{k W h} / \text { day })\end{array}$ & $\begin{array}{c}\text { Usage } \\
\text { energy } \\
(\mathbf{k W h} / \text { day })\end{array}$ & $\begin{array}{c}\text { Total EWH } \\
\text { energy } \\
(\mathbf{k W h} / \text { day })\end{array}$ & $\begin{array}{c}\text { Total EWH } \\
\text { energy } \\
(\mathbf{k W h} / \text { month })\end{array}$ & $\begin{array}{c}\text { Total HH } \\
\text { energy } \\
\text { (kWh/month) }\end{array}$ \\
\hline Baseline & N/A & 2.558 & 4.648 & 7.206 & 219.182 & 579.0 \\
\hline \multirow{3}{*}{$T_{\text {set }}$} & $55^{\circ} \mathrm{C}$ & 1.980 & 4.648 & 6.628 & 201.602 & 561.419 \\
\hline & $60^{\circ} \mathrm{C}$ & 2.269 & 4.648 & 6.917 & 210.392 & 570.21 \\
\hline & $70^{\circ} \mathrm{C}$ & 2.884 & 4.648 & 7.492 & 227.882 & 587.699 \\
\hline \multirow[t]{2}{*}{$T_{\text {ambient }}$} & $10^{\circ} \mathrm{C}$ & 3.126 & 4.648 & 7.774 & 236.459 & 596.277 \\
\hline & $15^{\circ} \mathrm{C}$ & 2.844 & 4.648 & 7.492 & 227.882 & 587.699 \\
\hline \multirow[t]{2}{*}{$T_{\text {inlet }}$} & $10^{\circ} \mathrm{C}$ & 2.523 & 6.949 & 9.472 & 288.107 & 647.924 \\
\hline & $15^{\circ} \mathrm{C}$ & 2.543 & 5.799 & 8.342 & 253.736 & 613.553 \\
\hline \multirow[t]{4}{*}{ Vusage } & $-5 \%$ & 2.562 & 4.417 & 6.979 & 212.278 & 572.095 \\
\hline & $-10 \%$ & 2.564 & 4.185 & 6.749 & 205.282 & 565.100 \\
\hline & $-15 \%$ & 2.567 & 3.951 & 6.518 & 198.256 & 558.073 \\
\hline & $-20 \%$ & 2.569 & 3.719 & 6.288 & 191.260 & 551.078 \\
\hline Thermal blanket & N/A & 2.167 & 4.648 & 6.815 & 207.290 & 567.107 \\
\hline Pipe insulation & N/A & 2.437 & 4.648 & 7.085 & 215.502 & 575.320 \\
\hline $\begin{array}{l}\text { Thermal blanket } \\
\text { + pipe insulation }\end{array}$ & N/A & 2.076 & 4.648 & 6.724 & 204.522 & 564.339 \\
\hline Schedule control & N/A & 1.825 & 4.648 & 6.473 & 196.887 & 556.705 \\
\hline $\begin{array}{l}\text { Schedule control } \\
\text { + thermal blanket } \\
\text { + pipe insulation }\end{array}$ & N/A & 1.501 & 4.648 & 6.149 & 187.032 & 546.850 \\
\hline 200 litre tank & N/A & 3.000 & 4.648 & 7.648 & 232.627 & 592.444 \\
\hline
\end{tabular}

\begin{tabular}{|c|c|c|c|c|c|}
\hline Variable & Value & $\begin{array}{c}\Delta \text { Standing } \\
\text { losses } \\
(\mathbf{k W h} / \mathbf{d a y})\end{array}$ & $\begin{array}{c}\boldsymbol{\Delta} \text { Usage } \\
\text { energy } \\
(\mathbf{k W h} / \mathbf{d a y})\end{array}$ & $\begin{array}{c}\boldsymbol{\Delta} \text { Total EWH } \\
\text { energy } \\
(\mathbf{k W h} / \mathbf{d a y})\end{array}$ & $\begin{array}{c}\boldsymbol{\Delta} \text { Total EWH } \\
\text { energy } \\
(\mathbf{k W h} / \mathbf{m o n t h})\end{array}$ \\
\hline$T_{\text {set }}$ & $55^{\circ} \mathrm{C}$ & -0.578 & 0.0 & -0.578 & -17.581 \\
\hline & $60^{\circ} \mathrm{C}$ & -0.287 & 0.0 & -0.287 & -8.730 \\
\hline & $70^{\circ} \mathrm{C}$ & +0.287 & 0.0 & +0.287 & +8.730 \\
\hline$T_{\text {ambient }}$ & $10^{\circ} \mathrm{C}$ & +0.574 & 0.0 & +0.574 & +17.459 \\
\hline & $15^{\circ} \mathrm{C}$ & +0.287 & 0.0 & +0.287 & +8.730 \\
\hline$T_{\text {inlet }}$ & $10^{\circ} \mathrm{C}$ & -0.006 & +0.686 & +0.680 & +20.683 \\
\hline & $15^{\circ} \mathrm{C}$ & -0.003 & +0.343 & +0.34 & +10.342 \\
\hline$V_{\text {usage }}$ & $-5 \%$ & +0.001 & -0.069 & -0.068 & -2.068 \\
\hline & $-10 \%$ & +0.001 & -0.138 & -0.137 & -4.167 \\
\hline & $-15 \%$ & +0.001 & -0.208 & -0.207 & -6.296 \\
\hline & $-20 \%$ & +0.002 & -0.277 & -0.275 & -8.365 \\
\hline Thermal blanket & N/A & -0.394 & 0.0 & -0.394 & -11.984 \\
\hline Pipe insulation & N/A & -0.124 & 0.0 & -0.124 & -3.772 \\
\hline $\begin{array}{c}\text { Thermal blanket } \\
+ \text { pipe insulation }\end{array}$ & N/A & -0.485 & 0.0 & -0.485 & -14.752 \\
\hline Schedule control & N/A & -0.686 & 0.0 & -0.686 & -20.866 \\
\hline $\begin{array}{c}\text { Schedule control } \\
+ \text { thermal blanket } \\
+ \text { pipe insulation }\end{array}$ & N/A & -0.995 & 0.0 & -0.955 & -30.265 \\
\hline 200 litre tank & N/A & +0.435 & 0.0 & +0.435 & +13.231 \\
\hline
\end{tabular}

an average saving of $13 \%$ savings, compared to only $5 \%$ for the same change in ambient temperature.

\section{ACKNOWLEDGEMENT}

The authors would like to acknowledge: MTN for their continued support and funding through the MTN Mobile Intelligence Lab. Eskom for their financial support.

\section{REFERENCES}

[1] M. J. Booysen, J. A. A. Engelbrecht, and A. Molinaro, "Proof of concept: Large-scale monitor and control of household water heating in near realtime," in Proc. of International Conference on Applied Energy (ICAE). Pretoria, South Africa, July 2013.

[2] M. G. Fikru and L. Gautier, "The impact of weather variation on energy consumption in residential houses," Applied Energy, vol. 144, pp. 19-30, 2015, DOI: 10.1016/j.apenergy.2015.01.040.

[3] R. K. Dutkiewicz, "Energy for hot water in the domestic sector," in Proc. of Domestic Use of Electrical Energy Conference. Energy Research Institute, 1997, pp. 6-11.

[4] I. E. Bosman, L. J. Grobler, and A. Z. Dalgleish, "Determination of the impact on the standing losses of installing blankets to electric hot water heaters in South Africa," Journal of Energy in Southern Africa, vol. 17, no. 2, pp. 57-64, 2006.

\begin{tabular}{|c|c|c|c|c|c|}
\hline Variable & Value & $\begin{array}{c}\Delta \text { Standing } \\
\text { losses } \\
\text { (kWh/day) }\end{array}$ & $\begin{array}{c}\Delta \text { Usage } \\
\text { energy } \\
\text { (kWh/day) }\end{array}$ & $\begin{array}{c}\Delta \text { Total EWH } \\
\text { energy } \\
\text { (kWh/day) }\end{array}$ & $\begin{array}{c}\Delta \text { Total EWH } \\
\text { energy } \\
\text { (kWh/month) }\end{array}$ \\
\hline$T_{\text {set }}$ & $55^{\circ} \mathrm{C}$ & -0.578 & 0.0 & -0.578 & -17.581 \\
\hline & $60^{\circ} \mathrm{C}$ & -0.289 & 0.0 & -0.289 & -8.790 \\
\hline & $70^{\circ} \mathrm{C}$ & +0.286 & 0.0 & +0.286 & +8.699 \\
\hline$T_{\text {ambient }}$ & $10^{\circ} \mathrm{C}$ & +0.568 & 0.0 & +0.568 & +17.277 \\
\hline & $15^{\circ} \mathrm{C}$ & +0.286 & 0.0 & +0.286 & +8.699 \\
\hline$T_{\text {inlet }}$ & $10^{\circ} \mathrm{C}$ & -0.035 & +2.301 & +2.266 & +68.924 \\
\hline & $15^{\circ} \mathrm{C}$ & -0.015 & +1.151 & +1.136 & +34.553 \\
\hline$V_{\text {usage }}$ & $-5 \%$ & +0.004 & -0.231 & -0.227 & -6.905 \\
\hline & $-10 \%$ & +0.006 & -0.463 & -0.457 & -13.900 \\
\hline & $-15 \%$ & +0.009 & -0.697 & -0.688 & -20.927 \\
\hline & $-20 \%$ & +0.011 & -0.929 & -0.918 & -27.923 \\
\hline Thermal blanket & $\mathrm{N} / \mathrm{A}$ & -0.391 & 0.0 & -0.391 & -11.893 \\
\hline Pipe insulation & $\mathrm{N} / \mathrm{A}$ & -0.121 & 0.0 & -0.121 & -3.680 \\
\hline $\begin{array}{c}\text { Thermal blanket } \\
+ \text { pipe insulation }\end{array}$ & $\mathrm{N} / \mathrm{A}$ & -0.482 & 0.0 & -0.482 & -14.661 \\
\hline Schedule control & $\mathrm{N} / \mathrm{A}$ & -0.733 & 0.0 & -0.733 & -22.295 \\
\hline $\begin{array}{c}\text { Schedule control } \\
\text { + thermal blanket } \\
+ \text { pipe insulation }\end{array}$ & $\mathrm{N} / \mathrm{A}$ & -1.057 & 0.0 & -1.057 & -32.150 \\
\hline 200 litre tank & $\mathrm{N} / \mathrm{A}$ & +0.442 & 0.0 & +0.442 & +13.444 \\
\hline
\end{tabular}

[5] L. Gelažanskas and K. A. A. Gamage, "Forecasting Hot Water Consumption in Residential Houses," Energies, vol. 8, pp. 12 702-12 717, 2015, DOI: $10.3390 /$ en 81112336.

[6] H. E. Jacobs and J. Haarhoff, "Structure and data requirements of an end-use model for residential water demand and return flow," Water SA, vol. 30, no. 3, pp. 293-304, 2004, DOI: 10.4314/wsa.v30i3.5077

[7] E. Hirst and R. A. Hoskins, "Residential Water Heaters: Energy and Cost Analysis ," Energy and Buildings, vol. 105, no. 1, pp. 393-400, 1978, DOI: $10.5942 /$ jawwa.2013.105.00118.

[8] J. P. Meyer, "A review of domestic hot water consumption in South Africa," Research \& Development Journal of the South African Institution of Mechanical Engineering, vol. 16, no. 3, pp. 55-61, 2000.

[9] P. J. C. Nel, M. J. Booysen, and B. van der Merwe, "A computationally inexpensive energy model for horizontal electrical water heaters with scheduling," IEEE Transactions on Smart Grid, 2016. 